\title{
THE COMBINATION OF CHEESE DAIRY AND AGRI-TOURISM AS A WAY OF DOING BUSINESS IN RURAL AREAS - CASE STUDY
}

\author{
MONIKA SCZYGIOL, ${ }^{1}$ VESNA MRDALJ, ${ }^{2}$ DRAGAN BRKOVIĆ ${ }^{3}$
}

${ }^{1}$ Wrocław University of Environmental and Life Sciences, POLAND

e-mail: monikasczygiol@gmail.com

${ }^{2}$ University of Banja Luka, BOSNA AND HERZEGOVINA

e-mail: vesna.mrdalj@agro.unibl.org

${ }^{3}$ University of Banja Luka, BOSNA AND HERZEGOVINA

e-mail: dragan.brkovic@agro.unibl.org

RECEIVED
ACCEPTED
JEL
CLASSIFICATION

KEYWORDS artisan cheese manufacturing, agro-tourism, non-agricultural activities, farm

ABSTRACT

\author{
20 April 2018 \\ 12 July 2018 \\ Q13
}

The main aim of this paper was to describe the activity of the artisan cheese dairy and agri-tourism on the example of the farm "Wańczykówka", which is located in the village of Krzeszów in the south Lower Silesia. The original source of information was used in the study, which was obtained by direct interview with the owner of the analyzed object. The farm is located in attractive tourist areas and has a good chance of developing non-agricultural activities as an additional source of income. The paper presents the motives for starting a business and characteristics of the farm profile. In addition, it was discussed the sourcing of raw materials and characterized the product variety, as well as the offer of agri-tourism services. The described artisan cheese dairy combined with agri-tourism is an excellent example of pursuing an interesting form of entrepreneurship in the countryside as well as promoting of local quality food.

\section{Introduction}

From the beginning of the $90 \mathrm{~s}$, the transformation of the Polish countryside based on exclusive agricultural production towards multifunctional villages has become visible. It gives the opportunity for the development of nonagricultural activity. The effect of these changes is the visible improvement of the economic situation of families living in rural areas (Firlej, 2000). The development of rural enterprise is determined by many factors, including 
natural values of the area, the share of economy and agriculture in the region, level of infrastructure, demographic situation, unemployment level and activity of local government (Kutkowska, 2003; Klepacka-Dunajko, Niewęgłowski, Kałuża, 2016). For a farms with a small area of agricultural land and a small share and turnover in the market, to use the chance to start non-agricultural activities become more important. In the last decade, there are changes in the agricultural structure which lead to the decline in the number of small farms for large-scale farms. Moreover, in recent years, the importance of non-agricultural income has increased in the household's total income (Błąd, 2011). On the basis of the General Agricultural Census of 2010, in Poland 36\% of farmers declare non-agricultural activity (Central Statistical Office of Poland, 2010). The Examples of business in the country may include: food processing or activities in the area of agri-tourism (Kutkowska, 2003). Multifunctional rural development is a important component of agriculture and rural development policy. Its main idea is to improve living and working conditions in the countryside and increase the share of non-agricultural employment. The realization of the above aims is to contribute to the perception of the village as an attractive place to live and work (Balińska, Zawadka, 2013).

\section{Materials and methods}

The aim of this paper is to present an idea for multidirectional economic activity in rural areas combining farm with artisan cheese dairy and agri-tourism services. The object of study was the "Wańczykówka" farm which is an example of the multidirectional form of enterprise in the countryside as well as the promotion of local quality food. The analyzed object is located in Krzeszów (Lower Silesian Voivodeship, south-western Poland). The study based on original source of information, which was obtained by direct interview with the owners of the analyzed object. In the interview was used a questionnaire with open-ended research questions. Besides the primary data, study based also on the secondary sources which are derived from available statistic and specialist literature. A case study was used as the main research method, furthermore it was used a study of the literature of the subject and descriptive method.

\section{Agri-tourism in Lower Silesia}

The trends in the field of agri-tourism farm has significant grew from 1996 to 2009, but their number in 2010 decreased. Since then, the popularization of agri-tourism business has been increased. On the figure 1 has shown the number of agri-tourism in Poland and in Lower Silesia (Maltegiewicz, 2015).

Lower Silesia is largely diversified in terms of agricultural conditions. Apart from the regions with high agricultural potential, this region is consisted of farms with unfavorable conditions such as the mountainous region of the Sudeten. Because of the nonhomogeneous conditions, Lower Silesia is divided into 5 regions (Marshal Office of the Lower Silesian Voivodship, 2001):

- Region I of intensive agriculture,

- Region II of agriculturally recreational,

- Region III of industrially, recreationally and touristic,

- Region IV of agriculturally industrial,

- Region $\mathrm{V}$ of agriculturally industrially and recreational.

Krzeszów belongs to the county of Kamienna Góra, which qualifies as industrially, recreationally and touristic subregion (Region III) (Witek, 1993).This area is characterized by medium development conditions, due to the low productivity of agricultural production (the share of farms in relation to the voivodeship average $15 \%$ ). The advantage 


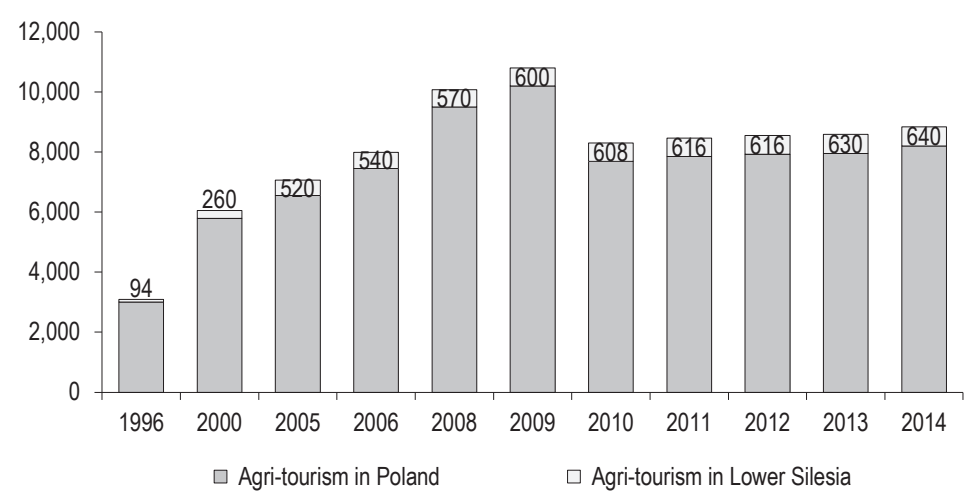

Figure 1. The number of Agri-tourism farm in Poland in 1996-2014

Source: based on Maltegiewicz (2015); Kurtyka-Marcak, Kutkowska (2015).

of the region is the value of the natural environment, that is why it has great potential in providing agri-tourism services. This area creates conditions for extensive or specialized agriculture based on cereals, potatoes and animal production, mainly for cattle or sheep (Marshal Office of the Lower Silesian Voivodship, 2001). Krzeszów is well known for its Cistercian Abbey, consisting of a cloister, two churches, including the baroque Basilica and the mausoleum. It is an ideal place for religious tourism. Among the beauties of the fields and forests are straggled stations of the cross, which are named Kalwaria Krzeszowska (National Heritage Institute, 2017).

\section{The combination of cheese daipy and agri-tourism - case study}

It is often observed that owners of small and medium-sized farms have a desire to make direct sales (Motowidlak, 2009).On the other hand since the end of the 20th century the union consumers have come back to the consumption of regional foods offered in direct sales. (Nowak, Tańska-Hus, Minta, 2011) It was similarly in the case of Lucyna and Sylvester Wańczyk, who started their business with direct sales of eggs, pork and milk obtained from their own cow. A large mobilization for owners has been the growing demand for their products among the inhabitants of Wroclaw, the capital of the voivodship. There was no indication that the owners would be willing to take activity in term of agri-tourism. The key factor that changed the attitudes of owners was the appearance of a cow in farm and the problem of milk processing, which proved to be too large for the needs of a five-person family. The owner's culinary passion solved the problem of the large amount of milk that was used to make homemade cheeses for the family. Confirmation of the rightness of the start of cheese making was a visit in 2007 to the "Polagra" food fair in Poznań during which one of the exhibitors presented cheeses which enjoyed great interest among visitors. A visit to the fair has become an incentive to start producing their own cheeses.

The problem of milk processing touched many farms. The crisis in the dairy market, and then the decline in the profitability of farms holding a few cattle, has given idea for a new direction in the field of cheese production. Polish farmed cheese is a young product on the market. Their name was given and popularized by Eugeniusz Mientkiewicz, a prominent cheese maker. At present, the value of farms cheese are fully appreciated and popularized at special fairs and periodic events (Wieczorek, 2012). Currently the importance of regional products is growing as an alternative to mass-produced products. This trend can be defined as regionalism (Minta, 2015). 
Direct sales and cheese production could not go together in the "Wańczykowka" farm. Due to the potential of cross-contamination, the Veterinary Inspection has imposed on owners the obligation to focus on one profile of their business and therefore they left the direct sales for artisan cheese dairy and agro-tourism.

\section{Fapm}

The size of the farm is 40 hectares, of which 30 hectares are leased. On arable land is allocated 17 hectares, while on grassland 23 hectares. The soils are rated for class IV and V. Cattle breeding of red-and-white as well as jersey in amount of 14 are aimed at the production of organic milk used for the production of yoghurts. In addition, there are 35 goats on the farm. Milk for cheese and yoghurt production is obtained from selectively chosen 3 local farms. Milk comes from own production (in the season from 6 milk cows is produced 160 I milk). The milk of own production (kept separately) is certified by the AgroBiotest's organic milk.

\section{Production: employment, equipment}

On the "Wańczykówka" farm, there are 6 salaried employees (4 production workers, 1 office worker, 1 distribution worker). For the production purposes there are used $500 \mathrm{I}$ of milk a day, which amounts to 3,500 I per week. Most cheeses are made from unpasteurized milk, so high microbial quality milk is important for their production. Pasteurization influences the deterioration of the organoleptic characteristics of the milk, so in order to preserve the taste values, the pasteurization process has been abandoned. In the artisan cheese dairy are specify facilities, like social room, production room, milk storage, fresh products storage, (a point of sale with the possibility of packaging products) and 2 maturating cellars. The proper conditions must be provided in the maturating cellars: humidity: $82 \%$ for Gouda cheese, $85-90 \%$ for blue cheese, temperature: $12-14^{\circ} \mathrm{C}$. Cheese dairy has the following equipment: cheese boilers with capacity of $20 \mathrm{I}, 300 \mathrm{I}$ and 1,000 I, press, pre-dripping bath, dosing pump, incubation cabinet, chiller, buttermilk, milk centrifuge and dishwashing machine. In the manufactory is strictly compliance with GMP/GHP requirements and there are taken some controls test like: $\mathrm{pH}$, pasteurization temperature and humidity.

\section{Products}

In the cheese manufacture are produced: bio-quality yoghurts (produced from organic bio-milk with biocertificated food additives, which production will be increase in the future), cottage cheese, rennet cheese, blue cheeses and semi ripened and ripened cheeses. For production are used milk from cows, goats and in the future also from sheeps.

\section{Distribution}

The product is delivered from Krzeszów to 27 points in Lower Silesia, mainly to Wroclaw. In addition, the products are directed into 5 restaurants. This product is available in select delicatessen and health food stores. Due to the high quality of the products and the high work input (craft production) these products reach a rather narrow recipient who want to pay more for the product in exchange for the distinctive organoleptic qualities.

\section{Agroturism}

The house of the Wańczyk family, which used to be a forester's lodge, is located nearby the forest. The location of the farm and the natural values made the farm an attractive place for rest. "Wańczykówka" offers its guests 
contact with animals (cows, goats), playground, area for building campfire. At the beginning of the activity from the agri-tourist its offer was mainly used by friends from Poznań and guests coming to New Year's Eve. The agri-tourist services benefited families with children who suffered from excessive anxiety. Contact with animals and nature, as well as accompanying the residents during their daily duties, had a therapeutic effect.

Due to the growing demand for cheeses and yoghurts, owners seek to obtain approval of their activity, left the form of the marginal, local and limited activity. The Ordinance of the Minister of Agriculture and Rural Development of 8 June 2010 defines when an activity may be called marginal, local and limited (Journal of Laws from 2010, No. 113 item 753). This activity include the scope and area of production. For example the limit of dairy products, amount to $300 \mathrm{~kg}$ per week. According to the new regulations, the limits on sales at the place of production were abolished. The Regulation also specifies the scope of the distribution area, which is limited to the voivodship in which the production takes place or to neighboring voivodships (Ditrich, n.d.). Marginal, local, limited sales simplify the small farmers to enter the market. Moreover it abbreviate the issues related to the approval of activities (related to technological design) and documentation or official controls. The owners are required to observe the Good Hygiene Practice (GHP) and Good Manufacturing Practice (GMP) without having to implement the HACCP system (Hazard Analysis and Critical Control Point) (Winawer, 2013).

The artisan cheese manufacturing is currently build up and growing its production. In the near plans it will be set up in the "Wańczykówka" Farmer's Cheese Academy, as a response to the growing demand for artisanal cheese production.

\section{Conclusions}

Since the end of the 90 s of the last century to the present day Poland agriculture is going through a transition, where the small scale farms diversify into other non-agricultural activities. This is confirmed by $36 \%$ of farms in Poland engaged in non-agricultural activities according to Agricultural census.

Multifunctional agriculture promoted through the EU Common Agricultural Policy has provided different role of agriculture, not only as an activity focused primarily on food production and ensuring of self-sufficiency, but also the creation of so-called non-market externalities in terms of the application of good agricultural practices and the integration of agriculture with other branches. The main objective of these activities is to improve the working and living conditions on farms in rural areas.

Objective of research in this paper showed that the Polish rural areas in particular in Lower Silesia are possible to generate income from other sources not only through the agricultural production but also tourism. This statement is confirmed by the case study farm "Wańczykówka" that is example of multidirectional form of enterprise in the countryside.

The idea for the establishment of such farm has resulted from the fact that the milk market had a crisis and reduced the profitability of small farms induced by low amount of animals. For this reason, in order to maintain their farm they reoriented towards a new production direction in the field of cheese production.

Through a wide variety of farm products "Wańczykówka" has managed to achieve a higher market share and increase in production. Also traffic channel for this farm are a local points in the Lower Silesia who are willing to pay more for these high-quality products.

Countryside of the Lower Silesia and the location of the farm "Wańczykówka" made it possible to farm develops in the direction of agro-tourism. 
The farm is planning to expand into other non-agricultural activities, such as the launch of "Wańczykówka" Farmer's Cheese Academy as a response to the growing demand for artisanal cheese production.

Farm "Wańczykówka" is an example of good practice in terms of linking agriculture and tourism on small farms in Lower Silesia. This case can be used as a model for future transformation of small scale dairy farms in Poland. Which contribute to the increased quality of life and revitalization of economic activities in rural areas.

\section{References}

Balińska, A., Zawadka, J. (2013). Znaczenie agroturystyki w rozwoju obszarów wiejskich. Retrieved from: http://keekid.wne.sggw.pl/ wp-content/uploads/2013/01/Turystyczne-funkcje-obszar\%C3\%B3w-wiejskich.pdf (15.04.2017).

Błąd, M. (2011). Pluriactivity in agricultural families in Poland. Status quo and trends of changes in 2005-2010. Zagadnienia Ekonomiki Rolnej, 2, 71-84.

Ditrich, B. (n.d.). Sprzedaż bezpośrednia. Działalność marginalna, lokalna i ograniczona. Retrieved from: http://podr.pl/doradztwo/ sprzedaz-bezposrednia (15.04.2017).

Firlej, K. (2000). Możliwość rozwoju przedsiębiorczości w polskim agrobiznesie. Roczniki Naukowe SERiA, 2 (8).

Central Statistical Office of Poland (2010). General Agricultural Census. Retrieved from: http://stat.gov.pl/obszary-tematyczne/ rolnictwo-lesnictwo/psr-2010/powszechny-spis-rolny-2010-obszary-wiejskie,1,1.html (15.04.2017).

Klepacka-Dunajko, I., Niewęgłowski, M., Kałuża H. (2016). Non -agricultural business in rural areas with high natural values. Stowarzyszenie Ekonomistów Rolnictwa i Agrobiznesu. Roczniki Naukowe, 2 (XVIII).

Journal of Laws from 2010, No. 113 item 753. Retrieved from: http://isap.sejm.gov.pl/DetailsServlet?id=WDU20101130753 (15.04.2017).

Kutkowska, B. (ed.) (2003). Podstawy rozwoju agroturystyki ze szczególnym uwzględnieniem agroturystyki na Dolnym Śląsku. Wrocław: Wydawnictwo Akademii Rolniczej we Wrocławiu.

Kurtyka-Marcak, I., Kutkowska B. (2015). Innowacyjność w turystyce wiejskiej na przykładzie gospodarstw agroturystycznych. Retrieved from: agro.travel/data/file/agro\%202015/../ll.1\%201.\%20Kurtyka-Marcak.ppt (15.04.2017).

Matlegiewicz, M. (2015). Agroturystyka-pozarolniczy biznes polskiej wsi. Ekonomia i Środowisko, 4 (55).

Minta, S. (2015). Regional food products: only for tourists or also for residents. The Journal of Agriculture and Forestry, 1 (61), 51-58. DOI: 10.17707/AgricultForest.61.1.06.

Motowidlak, U. (2009). Activity of farms in Poland in building a delivery chain. Retrieved from: http://www.wne.sggw.pl/czasopisma/pdf/ PRS_2009_T8(23)_s131.pdf (15.04.2017).

Nowak, M., Tańska-Hus, B., Minta, S. (2011). Sprzedaż bezpośrednia produktów regionalnych. Zeszyty Naukowe Uniwersytetu Przyrodniczego we Wrocławiu, 582. Seria Rolnictwo, 99, 81-92.

National Heritage Institute (2017). Register of monuments of Lower Silesia voivodeship. Retrieved from: http://www.nid.pl/pl/ Informacje_ogolne/Zabytki_w_Polsce/rejestr-zabytkow/zestawienia-zabytkow-nieruchomych/stan\%20na\%2031.03.2017/DLNrej.pdf (15.04.2017).

Marshal Office of the Lower Silesian Voivodship (2001). Studies on the development of Lower Silesia voivodeship. Retrieved from: www. umwd.dolnyslask.pl (15.04.2017).

Wieczorek, M. (2012). Ser prosto z zagrody. Top Agrar, 12, 8-9.

Winawer, Z. (ed.) (2013). Produkty regionalne i tradycyjne w krótkich łańcuchach produkcyjnych (Regional and traditional products in short production chains). Retrieved from: http://mazowieckie.ksow.pl/fileadmin/user_upload/mazowieckie/pliki/publikacje/2013/ efrwp-i.produkty_regionalne_i_tradycyjne.pdf (15.04.2017).

Witek, T. (ed.) (1993). Waloryzacja rolniczej przestrzeni produkcyjnej Polski według gmin. Puławy: IUNG.

Cite this article aS: Sczygiol, M., Mrdalj, V., Brković, D. (2018). The combination of cheese dairy and agri-tourism as a way of doing business in rural areas - case study. European Journal of Service Management, 3 (27/1), 307-312. DOI: 10.18276/ejsm.2018.27/1-39. 